Omni-Akuatika, 14 (3): 86-95, 2018
ISSN: 1858-3873 print / 2476-9347 online
Research Article
journal homepage: http://ojs.omniakuatika.net

\title{
Spawning Potential Ratio of Feather Back (Chitala Lopis) at Kampar River, Riau
}

\author{
Andri Warsa $^{1^{*}}$, Endi Setiadi Kartamihardja ${ }^{2}$, Arif Wibowo ${ }^{3}$ \\ ${ }^{1}$ Balai Riset Pemulihan Sumberdaya Ikan, Purwakarta, Jawa Barat, Indonesia \\ 2 Pusat Riset Perikanan, Jakarta Utara, Indonesia \\ ${ }^{3}$ Balai Riset Perikanan Perairan umum dan Penyuluhan Perikanan, Palembang, Sumatera Selatan, Indonesia
}

${ }^{*}$ Coresponding author: andriwarsa@yahoo.co.id

Received 31 July 2018; Accepted 28 November 2018; Available online 30 November 2018

\begin{abstract}
The feather back, Chitala lopis is an important economic fish, inhabit Kampar River and its population tend to decrease so that management and conservation efforts should be conducted. Limited data of the feather back is one of the problems in formulating the management of the population. Spawning potential ratio (SPR) approach is an option being used in the management of the fish stock in the poor data. The study aimed to analysis spawning potential ratio of the feather back in Kampar River, Riau. The research has been conducted in May, August and October 2016. The total length at first capture $\left(L_{c}\right)$ of feather back was less than the total length at first maturity $\left(\mathrm{L}_{\mathrm{m}}\right)$ with the SPR value of $5 \%$. This condition could impact to decreasing the feather back stock. The SPR value should increased more than $30 \%$ so the feather back population would been stable. Regulation of the fisheries was mainly limited mesh size of the gillnet operated should be applied.
\end{abstract}

Keywords: Habitat, spawning potential ratio, feather back, Kampar River

\section{Introduction}

Kampar River have a huge diversity of fish species, of which 58 species are found in Kampar Kanan (Fithra \& Siregar, 2010) and 86 species are found in Kampar Kiri River (Simanjuntak et al., 2006). The distribution of this species include Borneo, Java and Sumatera (Haryono, 2008). Feather back in Kampar River is important economically value but it's species in endangered status (Aryani, 2015). Stock of feather back in Kampar River was divided into two stocks zona, namely in upstream and downstream. The Feather back in Kampar River also shows different genetic characteristics with these species from Musi and Barito Rivers (Wibowo \& Marson, 2012). Feather Back is carnivore fish and can utilize fish juvenile, shrimp, insect, worm, benthos and plant as natural food (Burnawi, 2009; Wibowo, 2014). For the optimize and sustainable of harvest it need conservation and management for this species. This objectives of fish resource management is to optimize the production of harvest while maintaining the sustainability of resources, without over exploitation, and maintaining of stock health and also improving stocks condition (Cope \& Punt, 2009).

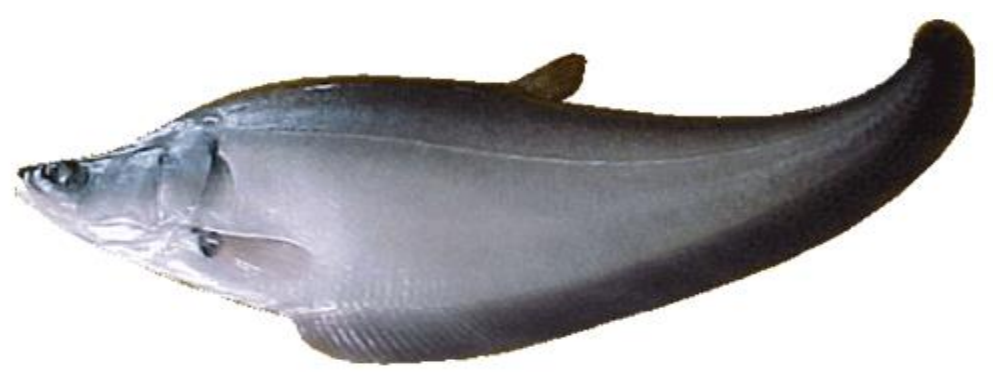

Figure 1. Feather Back (Chitala lopis Blkr) 
In generally, fisheries resource management is based on stock biomass and biological parameters of target fish (Wiedenmann et al., 2013; Carruthers et al., 2014). its model requires catches data on several years, the abundance of fish at a certainly age and the life cycle of target species (Deroba \& Bence, 2008), whereas the data about feather back fisheries in Kampar River is limited (poor data). Secondary data as production, number of fishing gear and trip, and number of fishermen in time series are not available. The approach that can be usage to determine the status of fisheries and formulate management with limited data (MacCall, 2009) can be done based on biological parameters ie infinity length, growth constant and length at first mature and length frequency (Wayte \& Klaer, 2010). The approach for feather back stock management with limited data with Spawning Potential Ratio (SPR) (Prince et al., 2011). SPR can be used as a basis for consideration in fisheries management with poor data (Hordyk et al., 2015a). SPR is the proportion of mature gonadal fish that is not exploited in capture activity (Prince et al., 2011). The objective of this research was to analyze spawning potential ratio as basic management and conservation of feather back stock at Kampar River, Riau Province.

\section{Materials and Methods}

\subsection{Research location}

The study was conducted in Kampar River, Riau Province at May, August and October 2016. Feather Back samples were obtained from fisherman catches at Pelalawan and Batu Sanggan locations and fish landing at Terata Teratak Buluh (Figure 2). Fishing gear were used include hook, gillnet and trap. The total length of the fish was measured using a measuring board with a precision of $0.1 \mathrm{~cm}$ and the weight of the fish was weighed using a scales with $100 \mathrm{~g}$ accuracy.

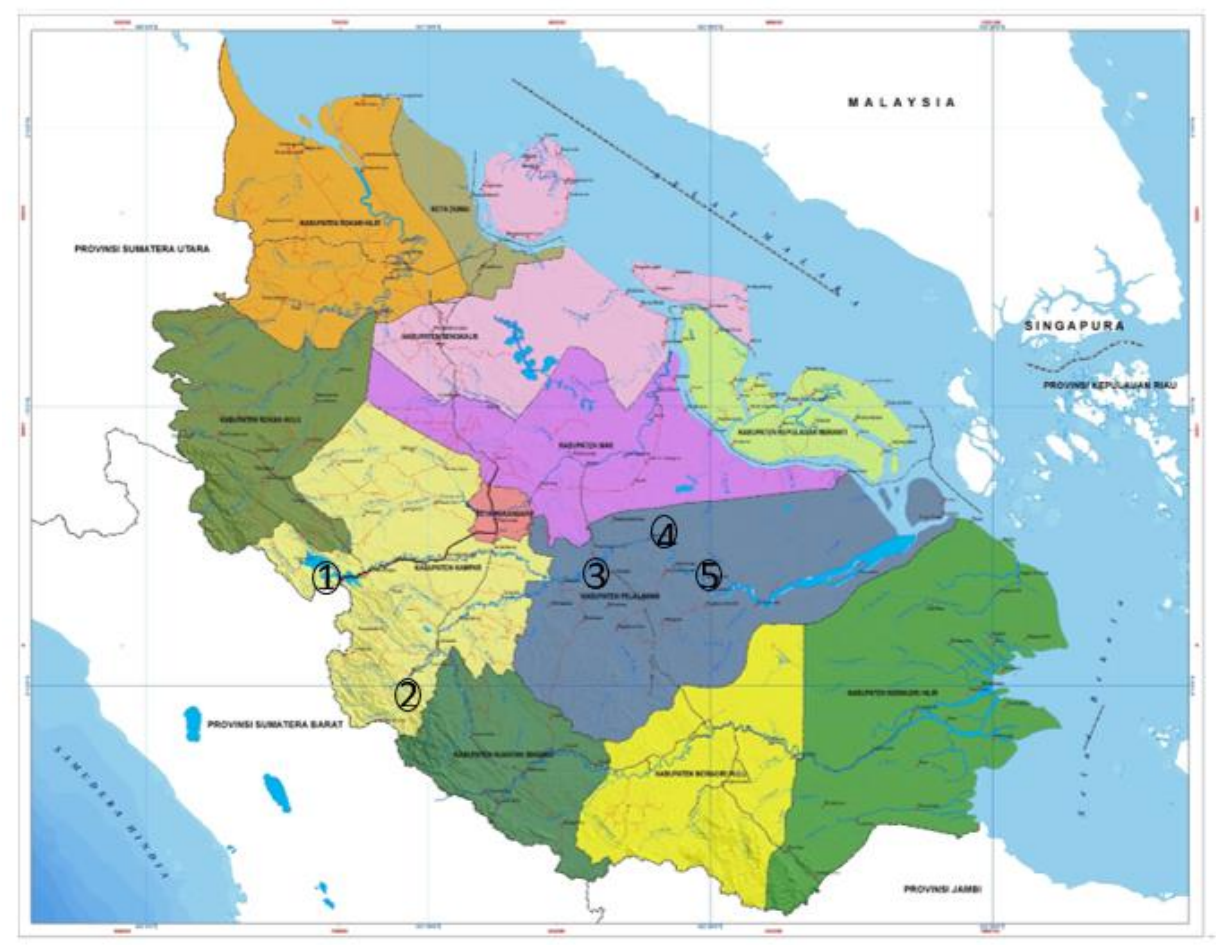

Figure 2. Sampling research at Kampar River 
Secondary data as production of fish was obtained from the Marine and Fisheries Agency, Riau Province. The Growth parameter as $\mathrm{K}$ and $\mathrm{t}_{\mathrm{o}}$ were obtained from desk study (Sani, 2010). The data of length frequency and maturity stage for male and female were obtained from Wibowo (2010).

\subsection{Data analysis}

\section{Growth patterns}

Growth pattern for feather back was analyzed using length-weight relationship with equations:

$$
\mathrm{W}=a L^{\mathrm{b}}
$$

Where:

$$
\begin{array}{lll}
\mathrm{W} & = & \text { Fish weight }(\mathrm{kg}) \\
\mathrm{L} & =\text { Total length }(\mathrm{cm}) \\
\mathrm{a} \text { and } & =\text { Regression } \\
\mathrm{b} & & \text { coefficient }
\end{array}
$$

Asympthotic length $\left(L_{\infty}\right)$

For $L_{\infty}$ estimation was calculated with Wetherall (1986) approach by the following steps:

1. The determination of lowest limit from the fish length range $(L T)$ was calculated by the equation:

$$
\overline{\mathrm{L}}=\sum F L / n
$$

Where:

$$
\begin{aligned}
\mathrm{F} & =\begin{array}{l}
\text { Total length frequency of } \\
\text { fish }
\end{array} \\
\overline{\mathrm{L}} & =\text { Middle total length of fish } \\
\mathrm{n} & =\text { Number of fish with total } \\
\mathrm{L}^{\prime} & =\begin{array}{l}
\text { Length is larger than } \mathrm{L}^{\prime} \\
\text { length limit value of total }
\end{array}
\end{aligned}
$$

2. Regression between $\bar{L}-L^{\prime}$ dengan L'

3. Ratio Z/K

$$
\begin{aligned}
& Z / K=-(1+b) / b \\
& L_{\infty}=-a / b
\end{aligned}
$$

\section{Where:}

$$
\begin{aligned}
& \mathrm{a}=\text { intercept } \\
& \mathrm{b}=\text { slope } \\
& \mathrm{k}=\text { Growth coefficient }
\end{aligned}
$$

\section{Length at first catch and mature of fish}

Length at first catch of father back was calculated using cumulative frequency curve (Beverton \& Holt,1975) with equation:

$$
L_{c}=\bar{L}-k\left(L_{\infty}-\bar{L}\right) / Z
$$

Where:

$L_{c}=$ Length at first capture $(\mathrm{cm})$

$\bar{L}=$ Average of total length of fish capture $(\mathrm{cm})$

$k=$ Growth coefficient $\left(\right.$ tahun $^{-1}$ )

$L_{\infty}=$ Asymptotic of total length $(\mathrm{cm})$

$Z=$ Total mortality rate $\left(\right.$ tahun $\left.^{-1}\right)$

The length of first mature $\left(L_{m}\right)$ was calculated using logistic curve (King, 2007) with formulation as:

$$
P=1 /(1+\exp [-r(L-L m)
$$

Where:

$$
\begin{aligned}
P & =\text { Proportion of fish mature }(\%) \\
L_{m} & =\text { The total length at stage mature } \\
& \text { of fish }(\mathrm{cm}) \\
\mathrm{L} & =\text { Total length of fish }(\mathrm{cm}) \\
\mathrm{R} & =\text { Slope }
\end{aligned}
$$

\section{Spawning potential ratio}

Spawning potential ratio (SPR) provides a conservation strategy to maintain the reproduction of a stock that is useful in preventing overfishing recruitment (Slipke et al., 2002). SPR methods are commonly used in the management of fish resources (Goodyear, 1993; Ault et al., 2005; Prince et al., 2015). Its can be used to define reference points for datapoor fisheries (Thorson et al., 2012). The SPR value is calculated based on Huo et al., (2015) equation as follows:

$$
S P R=\frac{S S B R_{r}}{S S B R_{r=0}} \times 100
$$

Where:

$$
\begin{aligned}
& S P R= \begin{array}{l}
\text { Spawning potential ratio } \\
\text { of fish (\%) }
\end{array} \\
& \mathrm{SSBR}_{\mathrm{r}}= \begin{array}{l}
\text { Spawning stock biomass } \\
\text { at exploitation }(\mathrm{kg})
\end{array} \\
& \mathrm{SSB}_{=0}=\begin{array}{l}
\text { Spawning stock biomass } \\
\text { unexploitation }(\mathrm{kg})
\end{array}
\end{aligned}
$$

The limits of the SPR values used as the basis for the management of fish resources (Goodyear, 1989; Clark,1991):
1. $\mathrm{SPR}<20 \%=$ Decreasing of fish population
2. $20 \% \leq$ SPR $>=$ Sustainable of fish $30 \%$ population
3. $\mathrm{SPR} \geq 35 \%=$ Increasing of fish population 
Estimated for length at first capture with optimally economic value

Estimation length of first capture with optimally economic value was calculated based on King (1995) approach. The calculation was done with some steps as:

1. Determination of fish length at age $t\left(L_{t}\right)$ (Sparre \& Venema, 1999)

$$
L_{t}=L_{o o}\left(1-e^{-k(t-t o)}\right)
$$

Where:

$$
\begin{aligned}
& \mathrm{L}_{\mathrm{t}}=\text { Length at } \mathrm{t} \text { age }(\mathrm{cm}) \\
& \mathrm{L}_{\mathrm{oo}}=\text { Asymptotic length }(\mathrm{cm}) \\
& \mathrm{k}=\text { Growth coefficient (per year) } \\
& \mathrm{t}_{\mathrm{o}}=\text { Theorytically age at zero } \\
& \mathrm{t} \quad \text { length (year) } \\
& \mathrm{t}
\end{aligned}
$$

2. Growth pattern was determined by length weight-relationship

3. Number of fish at $t$ time (King, 1995)

$$
\mathrm{N}_{\mathrm{t}+1}=\mathrm{N}_{\mathrm{t}} \exp (-\mathrm{M})
$$

Where:

$$
\begin{array}{ll}
N_{t+1}= & \begin{array}{l}
\text { Number of fish at time } \\
t+1 \text { (individual) }
\end{array} \\
N_{t}=\begin{array}{l}
\text { Number of fish at time } \\
t \text { (individual) }
\end{array} \\
M=\begin{array}{l}
\text { Natural mortality (per } \\
\text { year) }
\end{array}
\end{array}
$$

4. Total biomass of fish

$$
\mathrm{B}=\left(\mathrm{N}_{\mathrm{t}+1} \times \mathrm{W}\right) / 1000
$$

Where:

$$
\mathrm{B}=\text { Total biomass of fish }(\mathrm{kg})
$$

5. Economical value from fish harvest

$$
\mathrm{VE}=\mathrm{B} \times \mathrm{A}
$$

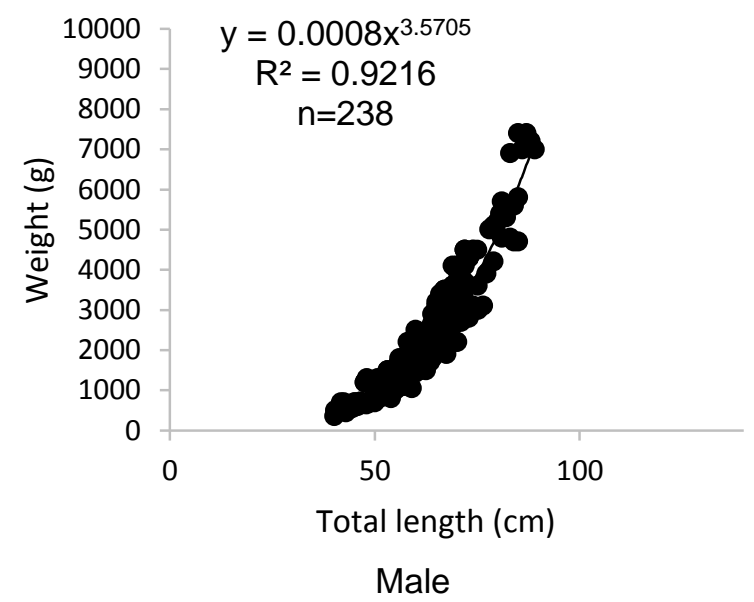

Where:

$$
\begin{aligned}
V E= & \text { Economic value from harvest } \\
(\mathrm{Rp}) & \\
A & =\text { Fish price }(\mathrm{Rp} / \mathrm{kg})
\end{aligned}
$$

\section{Result and Discussion}

The efforts of freshwater fisheries management are constrained due to the limited information about capture of fish, the size of the fish caught and fish stocks) (Suuronen \& Bartley, 2014). Management of fish resources can be done by setting the season and location of the capture, the number of catches and the size of the fish that can be captured (Andersen et al., 2018). The biology aspects of fish can be a reference in fisheries management, for example in determining the rules for fishing (Zhou et al., 2012) based on the Spawning potential ratio (Hordyk et al., 2015b). Total length and weight of feather back was catch in this research around $31,0-98,0 \mathrm{~cm}$ and $200-$ $8.200 \mathrm{gr}$ respectively. It's was larger than feather back that was catch at Riam Kanan Reservoir with total length and weight around $14-74,5 \mathrm{~cm}$ and $100-3300 \mathrm{gr}$ respectively (Umar \& Kartamihardja, 2007).

The Feather back fish were capture during the study ranged from $31.0-98.0 \mathrm{~cm}$ with a weight ranging from 200 to $8,200 \mathrm{~g}$. It was greater than the fish caught in Riam Kanan Reservoir, which range between 14-74.5 cm with a weight of 100-3300 g (Umar \& Kartamihardja, 2007). The length-weight relationship of female and male respectively follow the equation $W=0.0006 \mathrm{~L} 3,6269$ with value $R 2=0,9299$ and $W=0.0008 \mathrm{~L} 3,5705$ with value $R 2=0,9216$ (Figure 3 .)

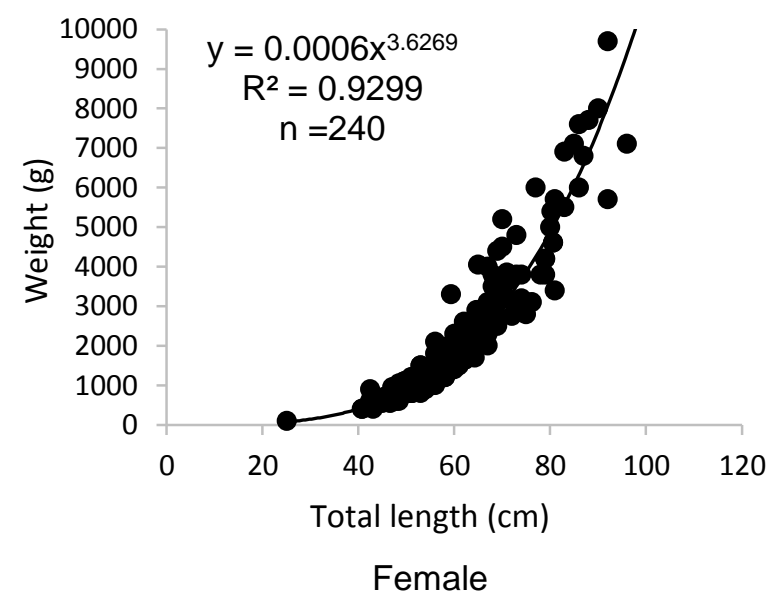

Figure 3. Length-weight relationships of feather back fish at Kampar River 
Growth patterns for male and female of feather back at Kampar River shown positive isometric $(p \geq 0,05)$. Its indicated that the increasing of the weight of fish was faster than increasing of length. The result was same with Lestari (2010) report, which was isometric positive for feather back with $b=3,4612$.

The average total length of fish was as an indicator of fish stock health (Klaer et al., 2012). Length data more informative for fisheries management (Ono et al., 2015). The cumulative frequency of the total length was captured during the study that presented in Figure 4. The most dominant total length was caught in this research were $55-60 \mathrm{~cm}$ for female and $60-70 \mathrm{~cm}$ for male. The total length was greater when it compared with the results of the study from Lestari (2010) namely around

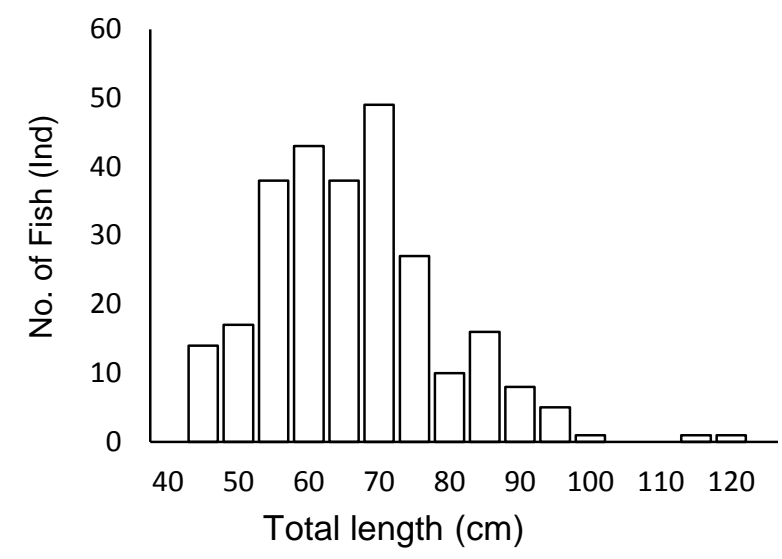

Male
$40-55 \mathrm{~cm}$. The asymptotic length $\left(L_{o o}\right)$ of feather back was estimated from the total length data frequency caught in the Kampar river $107.5 \mathrm{~cm}$ for 12,400 grams of weight. The asymptotic length of this study was greater when compared with Sani (2010) report was $96,1 \mathrm{~cm}$. The length of exploited fish data and biological parameters of fish can be the basis for determining fish resource management) (Kokkalis et al., 2015).

Estimates of the total length at the first capture $\left(L_{c}\right)$ for female and male fish were 45 and $53 \mathrm{~cm}$, respectively. The size of the first mature $(\mathrm{Lm})$ for female was $68 \mathrm{~cm}$ (Figure 5 ). The results of this study indicate that $L_{m}$ in this research was smaller when it compared with Subagja et al. (2010) namely $68.4-82.5 \mathrm{~cm}$ with an average of $75.6 \mathrm{~cm}$.

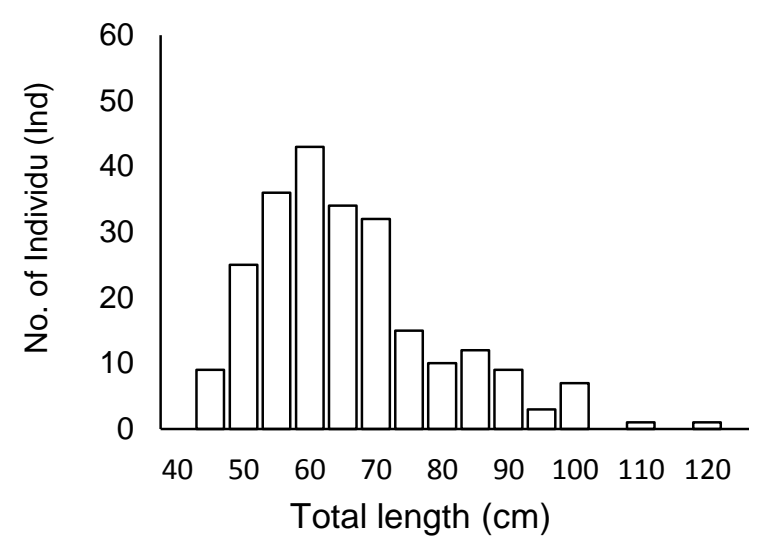

Female

Figure 4. Frequency distribution of feather back total length

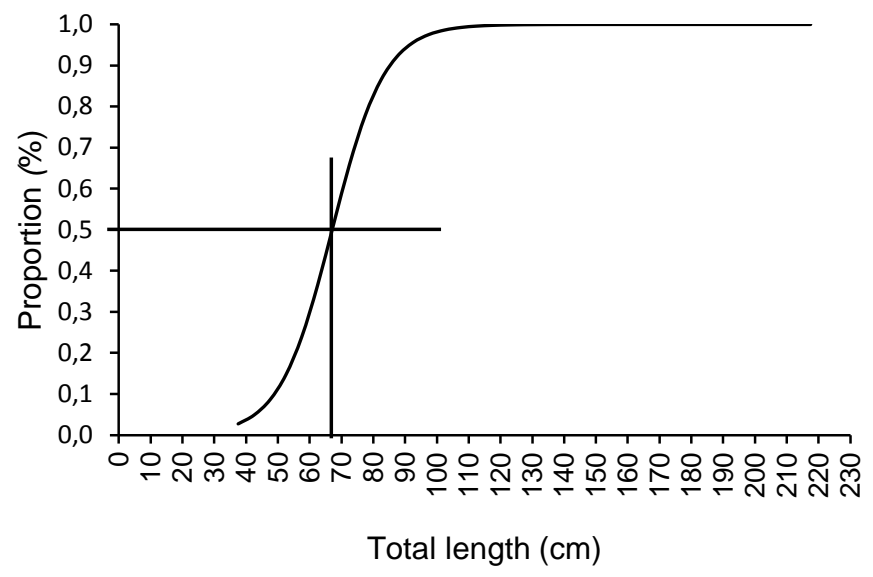

Figure 5 . The mean total length at first mature $\left(L_{m}\right)$ of feather back 
The Lm value for Chitala lopis species is greater than Notopterus notopterus species with a total length of $13.5 \mathrm{~cm}$ for male and 16.2 $\mathrm{cm}$ for female fish (Gustomi et al., 2016). These feather back spawning during the rainy season around November-February (Wibowo \& Sunarno, 2006). The total length size of the first fish caught (LC) was smaller than the size of the first fish matured gonad (Lm). Its continuously could caused pressure of feather back population so that caused no recruitment. The length at fish maturity can be the basis for determining the size of fish that can be caught so that it will ensure continuity of recruitment (Myers et al., 1999; Cope \& Punt, 2009; Conn et al., 2010). The Lc value must be greater than the Lm value (Babcock et al., 2013; Ambrose \&
Udo, 2015). Restricting fishing on the spawning population will warrant that all fish that survived until the start of the spawning period will be allowed to spawn (Overzee \& Rijnsdorp, 2015) thus ensuring stability and the number of fish populations (Cid et al., 2014). Management of fish resources based on SPR requires information on Lm (Midway \& Scharf, 2012).

The SPR value at the first captured $\left(L_{c}\right)$ was $5 \%$ while $30 \%$ of SPR value could been reached if the catch was in the length of fish after matured $\left(L_{m}\right)$ (Figure. 6). The SPR method is a method used in the determination of the length of the Exploitative Portunus pelagicus Linnaeus, 1758 in Belitung (Ernawati et al., 2015) and red drum in the Atlantic Ocean (Vaughan, 2002).

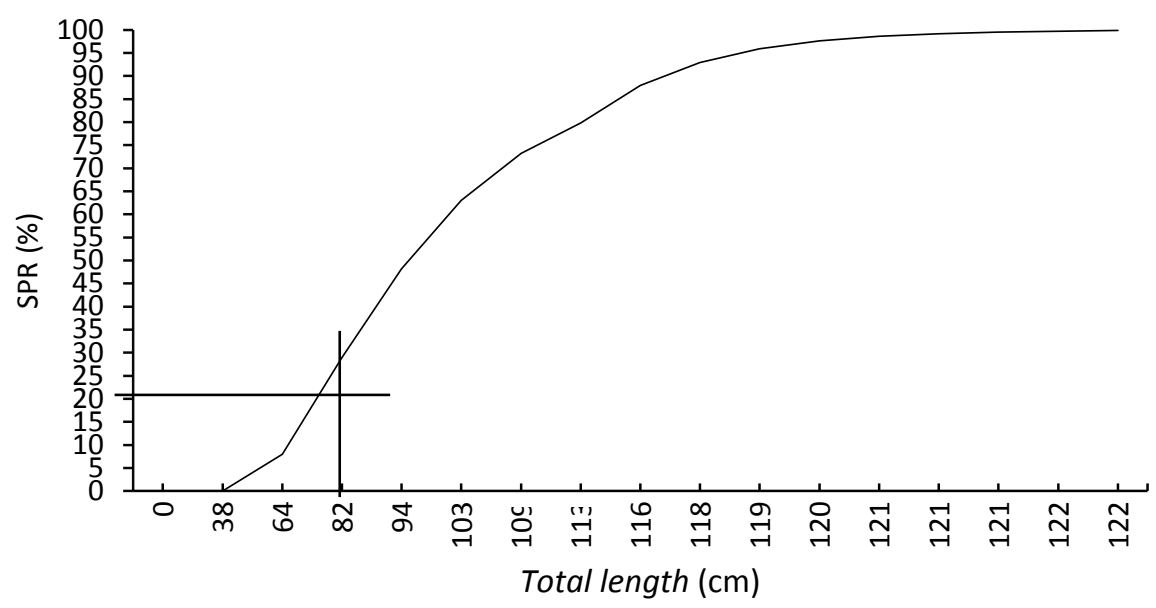

Figure 6. SPR Graphic and age of feather back at Kampar Riau

Based on $L_{m}$ value showed that feather back was capture before spawning and caused recruitment overfishing. SPR value must be greater $30 \%$ for maintain of sustainability population. Fish resources Management in the Hawaiian Islands also determinate by SPR value $>30 \%$ (Nadon et al., 2015). The effort for its in Kampar River as regulation of fish size for captured by limiting of mesh size of gear (Wibowo et al., 2010; Erisman et al., 2014), so that capture of fish with longer than $80 \mathrm{~cm}$. Restrictions on the size of fish that can be caught based on the value of the SPR are efforts of fish resources management (Klaer et al., 2012; Arlinghaus et al., 2010; Katselis et al.,
2010). The SPR can be a reference in determining of maximum sustainable yield (Legault \& Brooks, 2013) and prevent overfishing (Hordyk et al., 2016). Hal ini This related with sustainability of recruitment (Huo et al., 2015). Spawning stock is maintained so that the fish can reproduce before being caught (Froese et al., 2008; Wolf et al., 2015) and increased reproductive potential resulting from protection (Wilson et al., 2013). Exploitation of fish resources based on the SPR value is expected to be able rebuilding overfished stock back to sustainable level (Hordyk et al., 2015c) with revised reference points for exploitation (Cadrin \& Pastoors, 2008). 


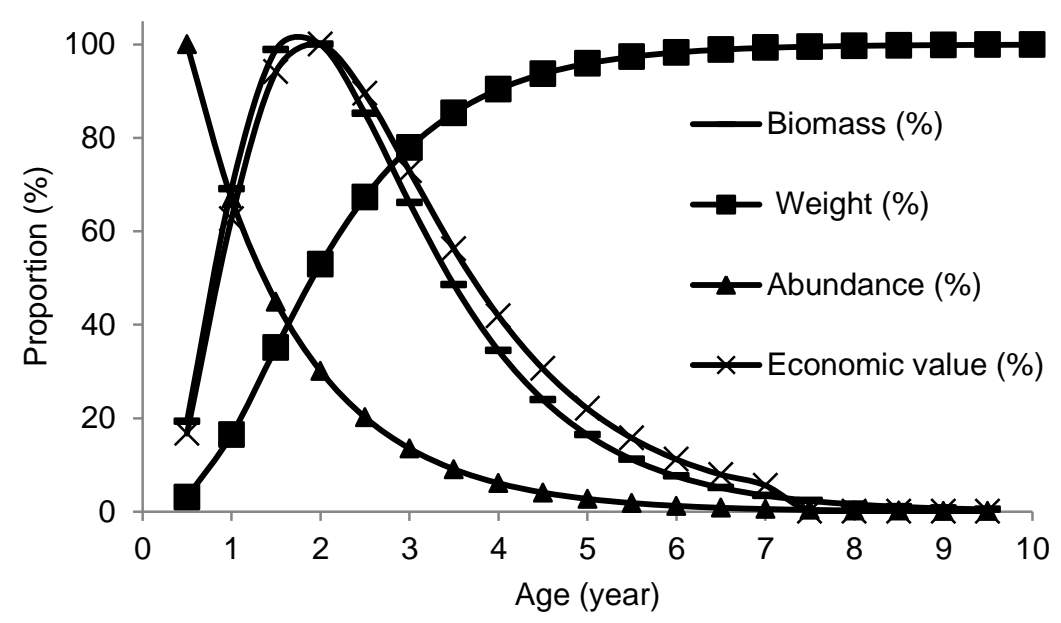

Figure 7. Relative biomass and economic value of feather back againts age

Regulation of fish caught will provide optimal economic value (Eikeset et al., 2013). Well-managed fisheries resources will provide optimal economic value (Dowling et al., 2008). Fishing carried out on) SPR $30-40 \%$ should result in high yield with minimal risk of collapse and contribute to rebuilding of overfished stocks (Midway \& Scharf, 2012). The highest economic value occurs when the harvest was done at total length of fish $\geq 80 \mathrm{~cm}$ or an average fish weight around $3.5 \mathrm{~kg}$ (Figure 7). Fish populations will decline gradually due natural mortality, which caused by predation or environmental degradation. The number of individual fish caught will be more if the exploitation is done less $80 \mathrm{~cm}$ of total length but the total biomass will become smaller. If exploitation is done at larger $80 \mathrm{~cm}$ the fish biomass will be optimal and economic valued too. This can happen because the caught fish has a larger individual size so that the total catch rate will be higher (Svedang, 2015).

\section{Conclusion}

The dominance of total length feather back was captured smaller than the length at first mature with SPR value was $5 \%$. To ensure of fish populations sustainability, SPR value must be greater than $30 \%$. This could be achieved if the total length of the exploited was $80 \mathrm{~cm}$. In addition, exploitation at this total length also provides the optimal economic value for fisherman.

\section{References}

Ambrose, E. E. A., M. T Udo. 2015. Length at first capture fpr Bonga, Ethmalosa fimbriata in Nigerian Inshore waters and management implication. International Journal of Fisheries and Aquatic Studies 2(6): 229-231.

Andersen, K. H., Marty, L., Arlinghaus, R. 2018. Evolution of boldbess anf lifehistory in response to selective harvesting. Canadian Journal of Fisheries and Aquatic Sciences 75(2): 271-281.

Arlinghaus, R., S. Matsumura., U. Dieckmann. 2010. The conservation and fishery benefits of protecting large pike (Esox Lucius L.) by harvest regulations in recrectional fishing. Biological conservation 143: 1444-1459.

Aryani N. 2015. Native species in Kampar Kanan River, Riau Province Indonesia. International Journal of Fisheries and Aquatic Studies 2(5): 213217

Ault J. S., S. G Smith \& J. A Bohnsack. 2005. Evaluation of average length as an estimator of exploitationstatus for the Florida coral-reef fish community. ICES Journal of Marine Science 62: 417-423.

Babcock, E. A., R. Coleman., M. Karanukas \& J. Gibson. 2013. Length-based indicators of a fishery and ecosystem status: Glover's Reef Marine Reserve, Belize. Fisheries Research 147: 434445. 
Burnawi. 2011. Pengamatan isi lambung ikan belida (Chitala lopis) hasil tangkapan di Perairan Sungai Kampar, Riau. BTL 9(1): 41-44.

Cadrin, S. X., Pastoors, M. A. 2008. Precautionary harvest policies and the uncertainty paradox. Fisheries Research 94: 367-372.

Cid, B., F. M. Hilker., E. Liz. Harvesting timing and its population dynamic consequencys in a discrete singlespecies model. Mathematical Biosciences 248: 78-87.

Clark, W. G. 1991. Groundfish exploitation rates based on life history parameters. Canadia Journal of Fisheries and Aquatic Science 48(5): 734-750.

Conn, P. B., E. H. Williams., K. W. Shertzer. 2010. When can reliably estimate the productivity of fish stocks. Can. J. Fish. Aquat. Sci. 67: 511-523.

Cope J. M., A, E Punt. 2009. Length-based reference points for data-limited situation: Apllications and restrictions. Marine and Coastal Fisheries: Dynamics, Management and Ecosystem Science 1: 169-186.

Carruthers, TR., Punt AE., Walters CJ., MacCall, A., McAllister MK., Dick EJ.,Cope J. 2014. Evaluating methods for setting catch limits in data-limited fisheries. Fisheries Research 153: 4868.

Deroba J. J \& J. R Bence. 2008. A review of harvest policies: Understanding relative performance of control rules. Fisherries Research 94: 210-223.

Dowling, N. A., D. C Smith., I. Knuckey., A. D. M. Smith., P. Domaschenz., H. M. Patterson., W. Whitelaw. 2008. Developing harvest strategies for lowvalue and data-poor fisheries: Case studies from three Australian fisheries. Fisheries Research 94: 380-390.

Eikeset, A. M., A. P. Richter., D. J. Dankel., E. S. Dunlop., M. Heino., U. Dieckmann., N. C. Stenseth. 2013. A bioeconomic analysis of harvest control rules for the Northeast Artic cod fishery. Marine Policy 39: 172-181.

Erisman, B. E., A. M. Apel., A. D. MacCall., M. J. Roman., R. Fujita. 2014. The influence of gear selectivity and spawning behavior on a data-poor assessment of a spawning aggregation fishery. Fisheries Research 159: 75-87.

Ernawati T., Duranta.,Wagiyo K. 2015. Penentuan status sumberdaya rajungan (Portunus pelagicus Linnaeus, 1758) dengan metode spawning potential ratio di perairan sekitar Belitung. J. Lit. Perikan. Ind 21(2): 63-70.

Fithra R. Y., Y. I Siregar. 2010. Keanekaragaman ikan Sungai Kampar inventarisasi dari Sungai Kampar Kanan. Jurnal lingkungan 2(4):139-147.

Froese, R., A. Stern-Pirlot., H. Winker., D. Gascuel. 2008. Size matters: How single-species management can contribute to ecosystem-based fisheries management. Fisheries Research 92: 231-241.

Goodyear, C. P. 1989. LSIM - A length-based fish population simulation model. NOAA Technical Memorandum NMFS-SEFC219 iii plus $55 \mathrm{p}$.

Goodyear C. P. 1993. Spawning stock biomass per recruitment in fisheries management: foundation and current use.In Smit SJ. J Hunt \& D Rivard (Edt). Rsik evaluation and biological reference points for fisheries Management. Can. Spec. Publ. Fish.Aquat. Sci 120: 67-81.

Gustomi, A., Sulistiono., Yonvitner. 2016. Biologi reproduksi ikan belida (Notopterus notopterus Pallas, 1769) di kolong-Bendungan Simpur Bangka. Jurnal IImu Pertanian Indonesia 21(1): 56-62.

Haryono. 2008. Potensi ikan belida dan upaya konservasinya. Fauna Indonesia 8(2): 58.

Hordyk, A. R., Ono, K., Valencia, S., Loneragan, N., Prince, J. 2015a. A novel length-based empirical estimation method of spawning potential ratio (SPR), and test of its performance, foor small-scale data poor fisheries. ICES Journal of Marine Science 72(1): 217231.

Hordyk, A. R., K. Ono., K. Sainsbury., N. Loneragan., J. Prince. 2015b. Some explorations of the life history ratios to describe length composition, spawningper-recruit, and the spawning potential ratio. ICES Journal of Marine Science 72(1): 204-216. 
Hordyk, A. R. N. R Loneragan., J. D. Prince. 2015. An evaluation of an iterative harvest strategy for data-poor fisheries using the length-based spawning potential ratio assessment methodology. Fisheries Research 171: 20-32.

Hordyk, A. R., K. Ono., J. D. Prince., C. J. Walters. 2016. A simple lengthstructured model based on life history ratios and incorporating size-dependent selectivity: application to spawning potential ratios for data-poor stocks. Canadian Journal of Fisheries and Aquatic Science 73(12): 1787-1799.

Huo B., B. S Ma. C. X Xie. Y. J Duan. X. F Yang., H. P Huang. 2015. Stock assessment and management implication of an endemic fish, Oxygymnocypris stewartii, in the Yarlung Zangbo River in Tibet, China. Zoological Studies 54: 1-15.

Katselis, G., K. Koukou., D. Moutopoulos. 2010. Yield per recruit and spawning stock biomass models for the management of four Mugilidae species in Mesolonghi-Aitoliko lagoon (W. Greece). Int Aquat Res 2: 155-162.

King M. 1995. Fisheries Biology, Assessment and Management. Fishing News Books. Berlin: 34p.

King, M. 2007. Fisheries biology, Assessment and Management. Blackwell Publishing. United States Of America. 382p.

Klaer N. L., S. E Wayte., G Fay. 2012. An evaluation of the performance of harvest strategy that uses an average -lengthbased assessment method. Fisheries Research 134-136: 42-51.

Kokkalis, A., U. H. Thygesen., A. Nielsen., K. $\mathrm{H}$. Andersen. 2015. Limited to the reliability of size-based fishing status estimation for data-poor stocks. Fisheries Research 171: 4-11.

Lestari M. 2010. Biologi reproduksi ikan belida (Chitala lopis) di daerah Aliran Sungai Kampar, Riau.Skripsi.Institut Pertanian Bogor. 60p.

Legault, M. C., E. N. Brooks. 2013. Can stockrecruitment points determine which spawning potential ratio is the best proxy for maximum sustainable yield reference points? ICES Journal of Marine Science 70(6): 1075-1080.
MacCall, A. D. 2009. Depletion-corrected average catch: a simple formula for estimating sustainable yields in datapoor situations. ICES Journal of Marine Science 66: 2267-2271.

Midway, S. R., F. S. Scharf. 2012. Histological analysis reveals larger size at maturity for southern Flouder with implications for biological reference points. Marine and Coastal Fisheries: Dynamics, Management, and Ecosystem Science 4: 628-638.

Myers, R. A., K. G. Bowen., N. J. Barrowman. 1999. Maximum reproductive rate of fish at low population sizes. Can. J. Fish. Aquat. Sci. 56: 2404-2419.

Nadon, M. O., J. S. Ault., I. D. William., S. G. Smith., G. T Dinardo. 2015. Lengthbased Assessment of coral reef fish populations in the Main and Northwestern Hawaiian Islands. PLOS ONE 10(8): 1-19.

Ono, K., R. Licandeo., M. L. Muradian., C. J. Cunningham., S. C. Anderson, F. Hutardo-Ferro., K. F. Jhonson. 2015. The importance of length and age composition data in statistical agestructured models for marine species. ICES Journal of Marine Science 72(1): 31-43.

Overzee, H. M. J., A. D. Rijnsdorp. 2015. Effect of fishing during the spawning period: implications for sustainable management. Reviews in Fish Biology and Fisheries 25(1): 65-83.

Prince J, D., N. A Downing. C. R Davies. R. A Campbell., D. S Kolody. 2011. A simple cost effective and scale less empirical approach to harvest strategies. ICES Journal of Marine Science 65(8): 947960.

Prince J. S Victor. V Kloulchad., A Hordyk. 2015. Length based SPR assessment of eleven Indo-Pasific coral reef fish population in Palau. Fish. Res (2015): http://dx.doi.org/10.1016/i.fishres.2015.0 $\underline{6.008 .}$

Sani O. 2010. Studi habitat dan pertumbuhan ikan belida (Chitala lopis) di daerah perairan Sungai Kampar, Provinsi Riau.Skripsi. 82 p.

Simanjuntak C. P. H. M. F Rahardjo., S. Sukimin. 2006. Iktiofauna rawa banjiran 
Sungai Kampar Kiri. Jurnal Iktiologi Indonesia 6(2): 99-1009.

Slipke J. W., A. D Martin. J. P Junior., M. J Maceina. 2002. Use of the spawning potential ratio for the Upper Mississipi River Channel Catfish Fishery. North American Journal of Fisheries Management 22: 1295-1300.

Subagja., Wibowo A., Marson.2010. Biologi reproduksi ikan belida (Chitala lopis) di dasrah aliran Sungai Kampar Riau. Seminar Nasional Tahunan VII: 1-9.

Suuronen, P.,Bartley, D. M. 2014. Challenges in managing inland fisheries-using the ecosystem approach. Boreal Environmental Research 19: 245-255.

Svedang, H. 2015. On size selectivity and $L_{\text {opt }}$ as a harvest strategy: replay to Froese et al. (2014). Fisheries Research 164: 331-332.

Thorson, J. T., J. M Cope. T. A. Branch., O. P Jensen. 2012. Spawning biomass reference points for exploited marine fishes, incorporating taxonomic and body size information. Can. J. Fish. Aquat. Sci. 69: 1-13.

Umar C., E. S Kartamihardja, 2007. Konservasi ikan belida (Chitala lopis) di Waduk Riam Kanan, Kalimantan Selatan.Dalam Rahardjo MF., et al. (edts). Forum Nasional Pemacuan Sumberdaya Ikan I: 263-272.

Vaughan, D. S. 2002. Estimating improvement in spawning potential ratios for South Atlantic Red Drum through Bag and size limit Regulations. North American Journal of Fisheries Management 22: 895-906.

Wayte S. E., N. L Klaer. 2010. An effective harvest strategy using improved catchcurves. Fisheries Research 106: 310320 .

Wetherall J. A. 1986. A new method for estimateing growth and mortality parameters from length-frequency data. Fishbyte 4(1): 12-14.

Wibowo A., M. T. D Sunarno. 2006. Karateristik habitat ikan belida (Notoptera Chitala): Bawal 1(1): 19-25.

Wibowo, A., Marson. 2012. Fenomena plastisitas fenotipik ikan belida (Chitala lopis) di Sungai Kampar, Riau. Bawal 4(3): 195-204.
Wibowo A. 2014. Food composition and niche characteristic of giant Feather Back (Chitala lopis) Bleek, Indoereivr 1851) In Kampar River, Indonesia.Fish. Res. J 20(1): 1-10.

Wiedenmann J., M. J Wilberg., T. J Miller. 2013. An evaluation of harvest control rule for data-poor fiheries. North American Journal of Fisheries Management 33: 845-860.

Wilson, J. R., S. R. Valencia., M. C. Kay., H. S. Lenihan. 2013. Integration of no-take marine reserves in the assessment of data-limited fisheries. Conservation Letter 7(5): 1-8.

Wolf, M., M. H. Taylor., G. Tesfaye. 2015. Implications of using small meshed gillnets for the sustainability of fish populations: a theoretical exploration based on three case studies. Fisheries Management and Ecology 22: 379-387

Zhou, S., S. Yin., J. T. horson., A. D. M. Smith \& M. Fuller. 2012. Linking fishing mortality reference points to life history traits: an empirical study. Can. J. Fish. Aquat. Sci. 69: 1292-1301. 